\title{
HOMELESSNESS: A HEALTH ISSUE
}

The following article is an edited version of a background paper prepared by Professor Ian Webster for the Public Health Association of Australia.

$\mathrm{H}$ melessness is a public health issue which is important not only because of the effects on health, but also because it tests the social roots of community health.

Father John Usher, of the Catholic welfare agency Centrecare, told a public meeting in 1988: "Adequate housing is the minimal physical condition to enable a household to create a home. This means much more than protection from the elements and overcrowding. It also implies security of tenure. A home is not a place where tenure is continually threatened and where external pressures are exercising undue control over the family's destiny."

As unemployment, housing costs and numbers on welfare increase, homelessness rises. Compared with the onceaccepted yardstick that public housing tenants spend 20 per cent of their income on rent, sole parents renting privately can pay between 32 and 43 per cent of their income on rent. Privately renting couples on the dole spend between 35 and 40 per cent on rent ${ }^{1,2}$.

Public concern about homelessness has been crystallised by the Burdekin Report on Youth homelessness ${ }^{3}$ and by other reports ${ }^{4,5,6,7,8}$.

Housing costs are a cause of poverty; and the lack of affordable housing is a major cause of homelessness.

In Australia, where home ownership is so highly valued, homeless people are marginalised, living outside the mainstream of society. Homelessness may deprive people of the basic necessities of life - personal space, privacy, food, possessions - and often leads to the point of irreversible social handicap. And with the widespread suspicion of welfare cheating and the desire that objective medical tests should be the criterion of invalidity, the environment is ripe for discrimination against the homeless disabled person needing income support through Social Security.

The groups at most risk for long-term homelessness are familiar to public health workers. They are Aborigines, migrant groups, single parent families, the long-term disabled and mentally ill people. These groups comprise a new underclass and are represented disproportionately among the homeless.

A homeless person was described by the Victorian Council to Homeless Persons as someone "without a conventional home and (who) lacks most of the economic and social supports that a home normally affords. $\mathrm{S} /$ he is often cut off from the support of relatives and friends, s/he has few independent resources and often has no immediate means and, in some cases, little future prospects of self-support. $\mathrm{S} /$ he is in danger of falling below the poverty line at least from time to time." 3

The health issues in homelessness are:

\begin{tabular}{l|l} 
Homelessness and impaired health are strongly \\
associated. \\
Patterns of living are unhealthy. \\
Access to health care is restricted. \\
Risks of infectious diseases are high.
\end{tabular}

One process contributing to the impaired health of homeless people is that there are few ways for them to meet their immediate emotional needs other than in potentially damaging ways - through smoking, alcohol consumption and drug use. The incentives to be "healthy" are hardly evident to people who are oppressed by their marginal social status.
The 1990 annual general meeting of the Public Health Association of Australia (PHA) resolved:

1 To express its concern at the level of homelessness in Australia. It is a major social issue with serious implications for public health. PHA strongly recommends that both Federal and State governments and the wider community should give the highest. priority to increasing the stock of affordable housing and the access of disadvantaged persons to accommodation of a reasonable standard.

2 Noting the lack of information about the extent and nature of homelessness and the needs of homeless people, PHA resolves, by all means possible, to promote collaborative research between epidemiologists, social scientists and other disciplines to develop methods for the study of the prevalence of homelessness.

3 Recognising the public concern about youth homelessness, PHA recommends that funding be provided to study the long-term outcomes of youth homelessness.

4 Noting the lack of data about homeless women and their needs, and the needs of homeless women and children, PHA recommends that high priority be given to these issues, both in terms of funding of targeted programs and research.

5 Recognising that the health of homeless persons is compromised by their social and physical environment and lifestyle patterns, PHA recommends that innovative approaches to health promotion be supported for this group, accompanied by thorough evaluation of their effectiveness.

6 Recognising that access to health care is frequently compromised for homeless people and their families, PHA recommends that existing primary health care services for homeless people be evaluated with a view to wider implementation. And that innovative approaches to health care, especially as it relates to homeless youth and women and the ageing homeless, be supported.

7 Noting the increasing problem of ageing and homelessness, PHA recommends that the Federal Government give consideration to directing the Home and Community Care Program to address this problem.

In this country the problem of homelessness is greatest in NSW, thus challenging the public health community in this State to become involved in practical and significant ways.

\section{Ian Webster}

Professor of Public Health

University of NSW

South Western Sydney Area Health Service

1. Saunders P, Whiteford P. Ending Child Poverty: An assessment of the Government's Family Package. SWRC Reports and Proceedings No. 69 , Nov 1987.

2. Bradbury, Rossiter and Vipond. Research on poverty 1986.

3. Our Homeless Children. Report of the National Inquiry into Homeless Children by the Human Rights and Equal Opportunity Commission. Canberra: AGPS, 1989.

4. Herra. A 4. Herrman and Singh B. Homeless People with Severe Mental Disorders in Inner 5 . Senate Standing Committee on Social Welfare Homeless Youth Report.

5. Senate Standing Com

6. Coopers and Lybrand, Scott WD. Department of Housing and

Construction 1985 Study into Homelessness and Inadequate Housing. Canberra: AGPS.

7. Raine MS, ed. Report of the Ministerial Inquiry into Homelessness and the Provision of Affordable Accommodation in the Inner City of Sydney, September 1988

8. Maas F, Hartley R. On the Outside: The Needs of Unsupported, Homeless Youth. Policy background paper No. 7, Australian Institute of Family Studies. 